\title{
Література:
}

1. Von Henting H. The Criminal and His Victim. Studies in the Sociobiology of Crime: monograph. New York: Schocken Books, 1979. 461 c.

2. Кулик О. Г. Злочинність в Україні на початку XXI століття : монографія. Київ: Юрінком Інтер, 2013. 272 с.

3. Демографический профиль жертв пре ступлений. Борьба $c$ преступностью за рубежом. 2014. № 4. С. 3-7.

4. Amin S. M. Ofiara przestępstwa we współczesnych systemach prawnokarnych ze szczególnym uzwględnieniem jurysprudencji Islamu. Toruń: Wydawnictwo Uniwersytetu Mikołaja Kopernika, 1995. 267 c.

5. Kuć M. Wiktymologia. Warszawa: Wydawnictwo C. H. Beck, 2010. $176 \mathrm{c}$.

6. Ривман Д. Криминальная віктимологія. Санкт-Петербург: Питер, 2002. $304 \mathrm{c}$.

DOI https://doi.org/10.30525/978-9934-26-074-2-52

\section{ПРАВОВІ ПІДСТАВИ ДІЙ ПРАЦІВНИКІВ НАЦІОНАЛЬНОЇ ПОЛІЦІЇ ПРИ ВИКОНАННІ ПОЛОЖЕНЬ Ч. 2 СТ. 10 ЗАКОНУ УКРАЇНИ «ПРО ЗАПОБІГАННЯ ТА ПРОТИДІЮ ДОМАШНЬОМУ НАСИЛЬСТВУ»}

\author{
Малиновська Т. М. \\ кандидат юридичних наук, доцент, \\ провідний науковий співробітник \\ Науково-дослідної лабораторії з проблем протидї злочинності \\ Харківського національного університету внутрішніх справ \\ Шорохова Г. М. \\ науковий співробітник \\ Науково-дослідної лабораторії з проблем протидї̈ злочинності \\ Харківського національного університету внутрішніх справ \\ м. Харків, Україна
}

Україна розвивається як демократична, соціальна та правова держава. Конституція України проголосила, що основні права і свободи людини й громадянина є найвищої соціальною цінністю.

Широке розуміння конституційного права на свободу і особисту недоторканність охоплює такі конституційні можливості, як особиста свобода і безпека, недоторканність житла, недоторканність таємниці 
листування, телефонних розмов, телеграфної та іншої кореспонденції, особистого і сімейного життя, честі й гідності, життя і здоров'я, свободи пересування, думки і слова, захисту в суді та інше.

Право на недоторканність житла та іншого володіння гарантується статтею 30 Конституції України і означає право на захист володіння людини від незаконних проникнень до них та будь-яких інших посягань [1]. Вхід у житло може відбутися тільки за згодою тих дієздатних осіб, які у ньому проживають. Ніхто не має права проникнути до житла чи іншого володіння особи 3 будь-якої метою, інакше як лише за добровільною згодою особи, яка ними володіє, або на підставі ухвали слідчого судді, крім випадків, установлених законом.

Законом України «Про Національну поліцію», у ст. 31 закріплені превентивні заходи, до переліку яких увійшло проникнення до житла чи іншого володіння особи (п. 7 ч. 1). Безпосередня деталізація даного заходу надана у ст. 38 Закону, зокрема встановлено, що поліція може проникнути до житла чи іншого володіння особи без вмотивованого рішення суду лише у невідкладних випадках, пов'язаних із: 1) рятуванням життя людей та цінного майна під час надзвичайних ситуацій; 2) безпосереднім переслідуванням осіб, підозрюваних у вчиненні злочину; 3) припиненням злочину, що загрожує життю осіб, які знаходяться в житлі або іншому володінні [2].

07.01.2018 року набрав чинності Закон України «Про запобігання та протидію домашньому насильству» в якому частиною 2 статті 10 передбачено, що поліцейські можуть проникати до житла особи без вмотивованого рішення суду в невідкладних випадках, пов'язаних із припиненням вчинюваного акту домашнього насильства, у разі безпосередньої небезпеки для життя чи здоров'я постраждалої особи.

Поняття «житло» у контексті змісту п. 1 ст. 8 Конвенції про захист прав людини і основоположних свобод охоплює не лише житло фізичних осіб. Воно може поширюватися на офісні приміщення, які належать фізичним особам, а також офіси юридичних осіб, їх філій та інші приміщення [3].

Відповідно до ст. 379 Цивільного кодексу України житлом фізичної особи є житловий будинок, квартира, інші приміщення, призначені для постійного проживання. Цивільний кодекс України окремо визначає такі об'єкти права власності, як житловий будинок, садиба, квартира [4].

Відповідно до Кримінального процесуального кодексу України під житлом особи розуміється будь-яке приміщення, яке знаходиться у постійному чи тимчасовому володінні особи, незалежно від його призначення і правового статусу, та пристосоване для постійного або 
тимчасового проживання в ньому фізичних осіб, а також всі складові частини такого приміщення (ч. 2 ст. 233) [5].

Під входженням розуміється встановлений i загальноприйнятий спосіб прибуття в житлові та інші приміщення - через двері, ворота, в’їди, хвіртки і інші місця, призначені для входу і виходу мешканців, персоналу, відвідувачів, або їх евакуації, а також в’їзду і виїзду транспортних засобів. Проникнення ж в разі необхідності може відбуватися також через вікна, стіни, паркани, підвали, горища, димоходи, каналізаційні, вентиляційні та інші інженерно-технічні системи, по землі, повітрю і будь-яким іншим обумовленим ситуацією шляхом.

Форми проникнення можуть бути різними: входження як таке, проникнення з використанням спеціальних пристосувань, технічних або транспортних засобів, в тому числі із застосуванням засобів руйнування перешкод, вогнепальної зброї, підручних засобів.

У той же час навряд чи доречно говорити про проникнення, якщо 3 урахуванням стану i зовнішнього вигляду об'єкту та організації його експлуатації знаходження на його території $\epsilon$ можливим для необмеженого кола осіб (наприклад, земельна ділянка не огороджена, іiі межі не позначені, будова зруйнована і закинута).

Аналогічна ситуація виникає i y випадках, коли мова йде про приміщення юридичних осіб, призначених для прийому відвідувачів, або коли приватне домоволодіння або дачна ділянка влаштовані таким чином, що для звернення до проживаючих там особам уповноважена особа вимушена пройти якусь відстань по двору, веранді і т.п. [6].

Оскільки недоторканність житла чи іншого володіння особи $\epsilon$ поняттям, яке включає в себе недоторканність приватного і сімейного життя особи, таємниці розмов у цьому житлі або іншому володінні й усього, що там відбувається та знаходиться, то під проникненням у житло чи інше володіння особи слід розуміти, як звичайне входження через двері та інші способи вторгнення, наприклад вторгнення через вікно, дах, стелю, підлогу чи стіну, так і складні форми вторгнення. Вилучення 3 житла чи іншого володіння особи будь-яких речей або підкидання таких речей за допомогою різного роду пристроїв, коли правопорушник перебуває поза межами житла чи іншого володіння [7].

Припинення вчинюваного акту домашнього насильства полягає в діях поліцейського, спрямованих на зупинення злочинної діяльності, що вже почалося, та на недопущення настання злочинного результату, що загрожує життю чи здоров’ю осіб, які знаходяться в житлі або іншому володінні. При цьому необхідно врахувати, що встановити наявність загрози для життя чи здоров'я через закриті двері оселі не завжди можливо [8]. 
Висновки. Загрози для життя чи здоров'ю людини встановлюється в кожному окремому випадку 3 урахуванням конкретних фактичних обставин. При вирішенні цього питання слід ураховувати як суб'єктивний критерій (сприйняття погрози потерпілим), так і об'єктивний (спосіб та інтенсивність їі вираження, особу винного, зв'язок і характер стосунків між ним і потерпілим тощо). Для визнання погрози вбивства реальною, необхідно встановити, що винний вчинив такі дії, які давали потерпілому підстави побоюватися іiї здійснення, і що поведінка винного та його стосунки 3 потерпілим об'єктивно свідчили про реальність погрози.

Проникнення до житла працівником поліції може бути здійснено за добровільною згодою особи. Разом з тим, нормативно-правовими актами не врегульовано питання у якій саме формі має бути викладена добровільна згода особи, яка є володільцем житла. Наприклад, особа (власник) може добровільно впустити працівника поліції до житла, а 3 часом відмовитись від своїх слів. Дії працівника поліції будуть вважатися як «незаконне проникненням до житла».

Для уникнення ускладнень в роботі органів Національної поліції, у разі коли особа спочатку надає таку добровільну згоду усно, тобто без перепон впускає до домовладіння поліцейського, краще щоб така згода була письмовою.

\section{Література:}

1. Конституція України: Закон України від 28 червня 1996 р. № 2 254к/96-ВР / Верховна Рада України. Відомості Верховної Ради Украӥни. 1996. № 30. Ст. 141.

2. Про Національну поліцію: Закон України від 2 липня 2015 р. № 580-VIII / Верховна Рада України. URL: http://zakon.rada.gov.ua/laws/ show/580-19 (дата звернення: 14.04.2021).

3. Конвенція про захист прав людини і основоположних свобод: Конвенцію ратифіковано Законом № 475/97-ВР від 17.07.1997 р. // База даних «Законодавство України». URL: https://zakon.rada.gov.ua/laws/ show/995_004\#Tеxt (дата звернення: 13.04.2021).

4. Цивільний кодекс України від 16.01.2003 p. № 435-IV // База даних «Законодавство України» / Верховної Ради України. URL: http://zakon2.rada.gov.ua/laws/show/435-15 (дата звернення: 14.04.2021).

5. Кримінальний процесуальний кодекс України від 13.04.2012 № 4651-VI. // База даних «Законодавство України» / Верховної Ради України. URL: http://zakon3.rada.gov.ua/laws/show/4651-17 (дата звернення: 14.04.2021). 
6. Бугайчук К.Л., Федосова О.В. Проникнення до житла чи іншого володіння особи в частині дотримання прав i свобод людини і громадянина (стаття 38 Закону України «Про Національну поліцію»): наук.-практ. рекомендації / Харків : Харк. нац. ун-т внутр. справ, 2019. $60 \mathrm{c}$.

7. Маляренко В.Т. Про недоторканність житла та іншого володіння особи як засаду кримінального судочинства // Верховний суд України. URL: http://www.viaduk.net/clients/vsu/vsu.nsf/(print)/75488B020FF6EC4 6C2257AF4003AE4E0 (дата звернення: 15.04.2021).

8. Ташматов В.А. Проникнення до житла чи іншого володіння особи як превентивний поліцейський захід. Південноукраӥнський правничий часопис. 2016. № 1. С. 108-112.

DOI https://doi.org/10.30525/978-9934-26-074-2-53

\title{
ГРУПА ОСІБ ЯК ОСОБЛИВО КВАЛІФІКУЮЧА ОЗНАКА КРИМІНАЛЬНИХ ПРАВОПОРУШЕНЬ ПРОТИ СТАТЕВОЇ СВОБОДИ ТА СТАТЕВОЇ НЕДОТОРКАННОСТІ ОСОБИ
}

\author{
Митрофанова Ю. С. \\ старший викладач кафедри кримінального права та кримінології \\ факультету № 6 \\ Харківського начіонального університету внутрішніх справ \\ м. Харків, Украӥна
}

Відповідно до ч. 1 ст. 28 Кримінального кодексу України (далі - КК) кримінальне правопорушення визнається таким, що вчинене групою осіб, якщо у ньому брали участь декілька (два або більше) виконавців без попередньої змови між собою [1]. Згідно ч. 2 ст. 27 КК виконавцем (співвиконавцем) $є$ особа, яка у співучасті з іншими суб'єктами кримінального правопорушення безпосередньо чи шляхом використання інших осіб, що відповідно до закону не підлягають кримінальній відповідальності за скоєне, вчинила кримінальне правопорушення, передбачене цим Кодексом. В науці кримінального права наголошується, що виконавцем (співвиконавцем) є особа, яка безпосередньо виконує діяння, що утворюють повністю чи частково об'єктивну сторону складу злочину [2, с. 186]. Отже, за змістом ч. 1 ст. 28 КК та ч. 2 ст. 27 КК кримінальне правопорушення може визнаватися вчиненим групою осіб, коли його вчиняють два співучасники як співвиконавці. Ознаками 